\title{
KEBIJAKAN SERTIFIKASI GURU (Tawaran Solusi Pendidikan Profesi Guru)
}

Ihyani Malik

Fakultas Ilmu Sosial dan Ilmu Politik Universitas Muhammadiyah Makassar

Jl. Sultan Alauddin No. 259 Makassar 90221

Telp. 0411 - 866972 ext. 107 Fax. 0411 - 865588

\section{ABSTRAK}

I ssu sertifikasi guru dan dosen telah lama digulirkan. Sertifikasi sebagai upaya legal dan pengakuan negara terhadap status profesional bagi guru. Undangundang RI No.14 tahun 2005 dan PP No.74 tahun 2008 memberikan batasan bahwa sertifikasi adalah proses pemberian sertifikat untuk guru dan dosen. Pengakuan sebagai seorang profesional dikuatkan dengan terbitnya lembaran negara yang bernama "sertifikat pendidik". Sebuah impian yang dinantikan oleh kaum "Umar Bakri" di Tanah Air. Namun menjadi sebuah tanda tanya, "apakah menjadi guru profesional cukup dengan sertifikasi?" Menjawab pertanyaan ini perlu dilakukan analisis lebih jauh.

Kata Kunci: Kebijakan, pendidikan, sertifikasi guru

\section{A. PENDAHULUAN}

Sejak pertama digulirkan, istilah sertifikasi telah membuat "gerah" beberapa LPTK (Lembaga Pendidikan Tenaga Kependidikan) di Tanah Air. Sertifikasi dianggap sebagai bentuk keraguan dari pihak pemerintah terhadap kredibilitas alumni dari LPTK yang telah banyak menghasilkan tenaga guru dan dosen. Lembaran negara berupa "Ijazah Akta" tidak menjadi sebuah jaminan kompetensi bagi setiap guru. Mengapa?

Issu tentang rendahnya mutu pendidikan yang seakan tak pernah selesai menjadi fakta tak terbantahkan sebagai indikator bahwa kompetensi guru perlu ditelusuri lebih jauh. Upaya untuk menelusuri pun "digodok" dalam rangka mendeteksi layak tidaknya seorang 
guru dianggap profesional. Tarik ulur sistem pendeteksian melahirkan sebuah instrumen yang disebut dengan "Penilaian Porto Folio" yang dianggap "lebih murah" saat ini sebagai "alat deteksi" bagi keprofesionalan bagi seorang guru.

Menyikapi pertanyaan utama di atas dikaitkan dengan "alat deteksi" berupa porto folio memang secara sederhana dapat menjawab pertanyaan tersebut. Porto Folio yang terbagi ke dalam 10 komponen besar yang dipersyaratkan dapat memberi jaminan bahwa seorang guru yang memenuhi standar poin minimal dari isi porto folio mereka layak dianggap profesional. Namun tentu saja semua yang menjadi item penilaian tersebut secara faktual merupakan pengalaman guru/ dosen yang benar-benar dilakoni dalam kehidupan nyata. Bagaimana ini?

Dengan persyaratan skor minimal dari isi porto folio (skor minimal 850) dan imbalan finansial yang cukup menggiurkan, berbagai upaya ditempuh oleh guru untuk mencapai derajat "profesional" tersebut. Dari berbagai sumber yang diperoleh (dari guru ataupun asesor) terdeteksi adanya usaha yang tidak "halal" dilakukan oleh calon profesional tersebut. Hal seperti ini memberi catatan tersendiri bahwa sebagian guru mengidap "penyakit moral" yang perlu diobati. Dari tangan asesor yang telah terlatih lahirlah guru yang layak dan tidak layak menyandang gelar "profesional". Guru yang layak diberi sertifikat, yang tidak layak di upgrade dalam suatu diklat khusus.

Penyakit moral yang disebutkan di atas muncul karena dua alasan yang berbeda. Ada yang bisa dibenarkan dan ada yang memang salah. Yang dapat dibenarkan adalah, mereka (guru/dosen) yang telah lama mengabdi secara benar atau "profesional" menurut penilaian lapangan, namun semua bukti fisik keprofesionalan yang telah diraih tidak dapat diperlihatkan (salah satu kelemahan penilaian porto folio). Yang tak dapat dibenarkan adalah guru yang melengkapi bukti isi porto folio mereka dengan carayang tidak benar (pemalsuan, plagiat, jual-beli piagam/sertifikat dsb).

Sertifikasi yang sedang terlaksana saat ini, dengan semua kelebihan dan kelemahannya harus diakui telah mampu menyaring beberapa guru/dosen yang layak dan tidak layak menyandang gelar profesional. Dari semua fenomena di atas, penilaian portofolio dan diklat adalah suatu upaya yang praktis dan cenderung lebih realistis sebagai langkah awal sertifikasi. Menyikapi semua hasil yang telah dicapai dari sertifikasi, memotivasi baik user ataupun stakeholder untuk memberikan sumbangan ide pemikiran demi menyempurnakan sistem yang sementara diberlakukan.

\section{B. KRITERIA GURU PROFESIONAL}

Mulyasa dalam bukunya "Menjadi Guru Profesional" (2006) menyoroti keprofesionalan guru dari segi proses pembelajaran. Mulyasa menekankan bahwa guru profesional harus mampu menciptakan pembelajaran kreatif dan menyenangkan. Dua kata terakhir "kreatif" dan "menyenangkan" diungkapkan dengan kata hubung "dan". Menurut logika bahasa kata "dan" mencakup dua hal yang tidak boleh berpisah. Kreatif dapat bermakna variatif, inovatif, atau baru dan harus dinikmati secara menyenangkan oleh pebelajar. Tuntutan kreatif dan menyenangkan terkesan sederhana tetapi dalam aplikasinya bukanlah hal yang gampang.

UU Sisdiknas 2003 pasal 39 (2) menyebutkan, pendidik merupakan tenaga profesional yang bertugas merencanakan dan melaksanakan proses pembelajaran, menilai hasil pembelajaran, melakukan pembimbingan dan pelatihan, serta melakukan penelitian dan pengabdian kepada masyarakat, terutama bagi pendidik pada perguruan tinggi.

Kriteria profesional yang disebutkan ini sudah sangat memadai apabila dimiliki oleh seorang guru/dosen. Kemampuan guru, mulai dari perencanaan sampai pada penilaian adalah kemampuan proses evaluasi untuk mendeteksi hasil yang akan dan telah dicapai. Sedangkan pelaksanaan penelitian merupakan upaya mengatasi masalah jika didapati adanya kesenjangan antara harapan dan kenyataan (anjuran pelaksanaan Penelitian Tindakan Kelas). Komponen inilah yang sebaiknya menjadi pantauan secara intensif pasca sertifikasi guru/dosen. Bagaimana perlakuan 
pasca sertifikasi? Jawabannya adalah tergantung user/stakeholder (masyarakat, pemegang kewenangan, dan semua yang berkepentingan dalam bidang pendidikan).

\section{SERTIFIKASI UNTUK MENJADI PROFESIONAL : SUATU TAWARAN SOLUSI ALTERNATIF}

Dua kriteria besar yang diungkapkan di atas menjadi acuan untuk mengajukan solusi merelevankan antara sertifikasi dengan profesionalisme. Mengajukan solusi dari suatu masalah haruslah bersifat realistis. Artinya dapat menjawab masalah dan terjangkau dari segi aplikasi, waktu, maupun dana. Dengan pertimbangan itulah sertifikasi guru yang dianggap dapat berdampak terhadap profesionalisme adalah sebagai berikut: (1) perlakuan pasca sertifikasi, (2) sistem pendidikan yang manusawi, (3) perekrutan tenaga pendidik profesional eksklusif, (4) pemberlakuan sistem kontrak secara profesional.

\section{PERLAKUAN PASCA SERTFIKASI}

Sertifikasi sudah bergulir dan yang dapat dilakukan untuk mewujudkan guru profesional adalah tindak lanjut pasca sertifikasi. Mewujudkan cita-cita tersebut, sangat tergantung bagaimana user/stakeholder meberikan perlakuan pasca sertifikasi.

Sekurang-kurangnya ada 6 hal yang dapat dilakukan mengenai perlakuan pasca sertifikasi, yaitu: (1) bagaimana user/ stakeholder menempatkan, memberikan, dan menugaskan guru profesional dengan opstimal, (2) mengawasi penyandang "guru profesional" tersebut membuktikan gelar baru yang disandangnya, (3) mengevaluasi dampak perlakuan user/stakeholder (kelebihan dan kekurangan) dengan melihat proses maupun hasil pendidikan yang telah dicapai, (4) mengidentifikasi masalah (kekurangan) dari hasil evaluasi, (5) merancang solusi alternatif yang dianggap dapat megurangi kekurangan/ kelemahan sertifikasi, (6) memberikan syarat kemudahan untuk mendapatkan imbalan finansial. Cara ini meskipun sifatnya klasik, namun bila dilakukan dengan tulus akan efektif.

\section{E. SISTEM KURIKULUM PENDIDIKAN YANG MANUSIAWI}

Sistem kurikulum pendidikan di Indonesia cenderung tidak manusiawi. Berikut ini beberapa sorotan yang patut dipertimbangkan oleh stakeholder pendidikan yaitu:

Pertama, muatan kurikulum. Dalam sebuah simposium reformasi pendidikan, Dr. Hafid Abbas, mengemukakan sebuah hasil analisis tentang kurikulum pendidikan dasar dan menengah bahwa, "Indonesia menempati posisi kedua kurikulum paling rumit di dunia sesudah negara Turki". Lebih lanjut dikatakan bahwa kerumitan kurikulum yang dimaksud adalah banyaknya cakupan kompetensi yang harus dicapai oleh peserta didik (siswa). Selain itu adalah jumlah mata pelajaran yang sangat banyak. Prof. Dr. Saleh Pallu, mengungkapkan bahwa Sekolah Dasar di Jepang hanya mengajarkan 2 mata pelajaran yaitu Matematika dan Fisika. Bandingkan dengan kurikulum pendidikan di Indonesia.

Kedua, kurikulum yang terkesan memaksa. Berdasarkan mata pelajaran dan standar isi, kurikulum pendidikan tidak memberikan pilihan yang lebih leluasa kepada peserta didik untuk menentukan pilihan berdasarkan minat dan bakat yang dimilikinya.

Ketiga, standar kompetensi lulusan yang tumpang-tindih dengan kriteria kelulusan ujian nasional. Penetapan KKM (Kriteria Ketuntasan Minimal) adalah otonomi penuh bagi guru mata pelajaran. Secara rasional siswa yang telah lulus KKM dari semua mata pelajaran setiap jenjang kelas sudah dianggap kompeten untuk lulus. Tetapi secara nasional melalui Ujian Nasional secara sepihak dapat menggagalkan semua itu dengan kriterianya sendiri.

Sistem kurikulum ini sangat mempengaruhi keprofesionalan guru sebab terkait dengan hasil belajar yang menjadi tolok ukur utama mutu pendidikan. Meskipun guru sudah dianggap profesional tetapi dengan sistem kurikulum seperti ini akan terpatahkan oleh fakta hasil belajar siswa akibat kerumitan muatan kurikulum yang dihadapinya. 


\section{F. PEREKRUTAN TENAGA PENDIDIK PROFESIONAL EKSKLUSIF}

Melahirkan profesional memerlukan perlakuan eksklusif (tidak umum). Eksklusif dalam perekrutan calon profesional (sistem seleksi), perlakuan calon profesional, dan apresiasi user/stakeholder setelah menjadi profesional. Salah satu kesalahan besar yang dilakukan pemerintah di negeri ini adalah perubahan IKIP (Institut Keguruan Ilmu Pendidikan) menjadi Universitas. IKIP adalah institusi eksklusif yang diformat untuk memproduksi guru. Dengan menggunakan nama IKIP maka secara rasio hanya "memanggil" secara eksklusif untuk mereka yang bercita-cita menjadi guru. Kebijakan mengubah IKIP menjadi Universitas berakibat pada tidak jelasnya institusi apa yang bertanggung jawab terhadap mutu guru.

Prof. Dr. Djaali (anggota BSNP), bahkan membuat wacana yang lebih eksklusif lagi tentang perekrutan guru. Dikatakan bahwa guru sebaiknya dieksklusifkan seperti pendidikan AKABRI (seleksi ketat, terpusat, dan diasramakan). Prof. Dr. Djaali meyakini hipotesis bahwa rendahnya mutu pendidikan bukan disebabkan oleh kompetensi guru, melainkan lebih pada "keikhlasan menjadikan profesi guru sebagai panggilan jiwa."

\section{G. PEMBERLAKUAN SISTEM GURU KONTRAK SECARA PROFESIONAL}

"Pemaksaan" meskipun terkesan bernilai negatif, namun sering membuahkan hasil yang optimal. Sistem kontrak secara profesional akan "memaksa" guru untuk selalu produktif. Dengan ancaman sanksi administratif sampai pada pemutusan kontrak, guru yang telah lulus seleksi dan dianggap layak, dengan serta-merta akan meningkat-kan kemampuannya. Sistem ini memang harus diimbangi dengan gaji yang cukup menjanjikan. Seperti sistem yang berlaku pada bidang profesional seperti, perusahaan, sepak bola, dunia hiburan, dan fashion.

\section{H. MENGINTIP SERTIFIKASI NEGARA SINGAPURA}

Sebagai negara yang berhasil dalam menuai hasil pendidikan Singapura cukup layak menjadi sorotan dalam hal sertifikasi. Sebuah paper berjudul "what the United States of America can learn from Singapore's world class mathematics system (and what Singapore can learn from the United States of America): An exploratory study", di dalamnya diungkapkan mengenai sertifikasi guru menjadi bagian dari kerangka kerja analitik selain entri, penyiapan, dan pelatihan profesional. Dalam paper tersebut dikemukakan bahwa di Singapura dukungan terhadap guru berkualitas dipersyaratkan untuk kualifikasi sarjana (Strata-1).

Kementrian Pendidikan Singapura menawarkan pengembangan profesionalisme melalui program pre-service learning, effective pedagogy, dan learn to understand new technologies and incorporate them into teaching (American Institutes for Research, 2005). Baik pre-service learning atau effective pedagogy, di Indonesia pun telah diprogramkan PPG (Pendidikan Profesi Guru) yang memiliki ide yang serupa.

Secara garis besar, sertifikasi yang dilakukan di Singapura tidaklah jauh berbeda dengan apa yang dilakukan di Indonesia. Tetapi membandingkan hasil pendidikan SingapuraIndonesia menunjukkan mutu yang berbeda. Padahal menurut hitungan, jumlah jam pelajaran yang dimiliki sistem persekolahan di Indonesia berada di atas rata-rata dibandingkan dengan negara lain yang maju di bidang pendidikan. Semestinya "jam belajar yang banyak" berbanding lurus dengan "mutu hasil belajar yang dicapai." Lalu di mana akar masalahnya? Untuk menjawabnya dibutuhkan eksperimen "berani" untuk mencoba tawarantawaran alternatif yang telah dikemukakan di atas.

\section{DAFTAR PUSTAKA}

Abidin, Said Zainal. 2009. Peran Pemerintah dalam Pembangunan. Ilmu Administrasi Vol. 4. No. 2 hlm.54 - 55.

Ahmad, H.Muh. Syarif. 2009. Pelaksanaan Otonomi Daerah Sangat Diperlukan 
Manajemen Sumber Daya Manusia yang Berkualitas. Adminstrasi Negara Vol. 15. No. 3. Hlm. 24.

Ahmadi, Abu. 1999. Psikologi Sosial. Jakarta: Rinneka Cipta

Ali, M. Sidin, Jaali, Syamsuddin Nonci. 1986. Evaluasi Pendidikan.Jakarta: Depdikbud Proyek Sisdiklat BKS PTN, Indonesia Timur.

Bycio, P., Hackett, R.D., and Allen, J.S. 1995. Further Assessments of Bass's (1985). Conceptualization of Transactional and Trans-formational Leadership. Journal of Applied Psychology, 80 (4): 468-478.

Dessler, Gary, 1997. Human Resource Management. Terjemahan Benyamin Molan. Jakarta : Prenhallindo.

Donaldson dan Scannel, 1993. Human Resources Development. Terjemahan Ya'kub dan Eno. Jakarta : Gaya Media Pratama.

Eisenbach, R., Watson, K., and Pillai, R. 1999. Transformational Leadership in The Context of Organizational Change. Journal of Organizational Change Management, 12 (2): 80 88.

Himpunan Peraturan Peundang-undangan Pegawai Negeri Sipil, 2003. Bandung : Fokus Media.

Judge, T.A., and Bono, J.E. 2000. Five-factors Model of Personality and transactional Leadership. Journal of Applied
Psychology, 85 (5): 751-765.

Jalaluddin dan Abdullah, 1997. Filsafat Pendidikan. Jakarta : Gaya Media Pratama.

Jessup, G., Jessup, H. (1975). Selection and Assesssment, London, Matheuen.

Koh, W.L., Steers, R.M., and Terborg, J.R. 1995. The Effect of Transformational Leadership on Teacher Attitudes and Student Performance in Singapore. Journal of Organizational Behavior, 16: 319-333.

Stolovitch, Keeps. 1992. Strategy Formulation in Complex Organization. New York: Mc Graw Hill Book Company

Suhartono, S. 1994. Filsafat Ilmu Pengetahuan. Ujungpandang: PPs UNHAS

Winkel, W.S. Psikologi Pengajaran. Jakarta: PT. Gramedia

Winarno, Budi. 2002. Apakah Kebijakan Publik : dalam Teori dan Proses Kebijakan Publik. Yogyakarta: Media Pressindo.

Yukl, G.A. 1998. Leadership in Organization. Second Edition. Englewood Clifs, New Jersey: Prentice-Hall, Inc.

Yuki, Gary 1998. Kepemimpinan Dalam Organisasi. Jakarta : Prenhallindo.

Zainun, Buchari, 1995a. Administrasi dan Mananajemen Kepegawaian Pemerintah Negara Indonesia. Jakarta : Gunung Agung. 